Marquette University

e-Publications@Marquette

Biological Sciences Faculty Research and

Publications

Biological Sciences, Department of

2-1999

\title{
Physiological and Morphological Correlates of Presynaptic Inhibition in Primary Afferents of the Lamprey Spinal Cord
}

\author{
I. V. Batueva \\ Russian Academy of Sciences \\ E. A. Tsvetkov \\ Russian Academy of Sciences
}

A. K. Sagatelyan

Yerevan State University

James T. Buchanan

Marquette University, james.buchanan@marquette.edu

N. Vesselkin

Russian Academy of Sciences

See next page for additional authors

Follow this and additional works at: https://epublications.marquette.edu/bio_fac

Part of the Biology Commons

\section{Recommended Citation}

Batueva, I. V.; Tsvetkov, E. A.; Sagatelyan, A. K.; Buchanan, James T.; Vesselkin, N.; Adanina, V.;

Suderevskaya, E. I.; Rio, J. -P; and Repérant, J., "Physiological and Morphological Correlates of Presynaptic Inhibition in Primary Afferents of the Lamprey Spinal Cord" (1999). Biological Sciences Faculty Research and Publications. 247.

https://epublications.marquette.edu/bio_fac/247 


\section{Authors}

I. V. Batueva, E. A. Tsvetkov, A. K. Sagatelyan, James T. Buchanan, N. Vesselkin, V. Adanina, E. I. Suderevskaya, J. -P Rio, and J. Repérant 
Marquette University

e-Publications@Marquette

\section{Biological Sciences Faculty Research and Publications/College of Arts and Sciences}

This paper is NOT THE PUBLISHED VERSION; but the author's final, peer-reviewed manuscript. The published version may be accessed by following the link in the citation below.

Neuroscience, Vol. 88, No. 3 (February 1999): 975-987. DOI. This article is (C) Elsevier and permission has been granted for this version to appear in e-Publications@Marquette. Elsevier does not grant permission for this article to be further copied/distributed or hosted elsewhere without the express permission from Elsevier.

\section{Physiological and Morphological Correlates of Presynaptic Inhibition in Primary Afferents of The Lamprey Spinal Cord}

\section{Batueva}

Sechenov Institute of Evolutionary Physiology and Biochemistry, Russian Academy of Sciences, St Petersburg, Russia

E Tsvetkov

Sechenov Institute of Evolutionary Physiology and Biochemistry, Russian Academy of Sciences, St Petersburg, Russia

A Sagatelyan

Yerevan State University, Yerevan, Armenia

J.T. Buchanan

Department of Biology, Marquette University, Milwaukee WI

$\mathrm{N}$ Vesselkin

Sechenov Institute of Evolutionary Physiology and Biochemistry, Russian Academy of Sciences, St Petersburg, Russia 


\title{
V Adanina
}

Sechenov Institute of Evolutionary Physiology and Biochemistry, Russian Academy of Sciences, St Petersburg, Russia

\section{E Suderevskaya}

Sechenov Institute of Evolutionary Physiology and Biochemistry, Russian Academy of Sciences, St Petersburg, Russia

\section{J.-PRio}

INSERM U106, Paris, France

J Repérant

\author{
INSERM U106, Paris, France
}

\begin{abstract}
Patch-clamp recordings in a whole-cell mode were performed on dorsal sensory cells enzymatically isolated from the spinal cord of two lamprey species, Ichthyomyzon unicuspis and Lampetra fluviatilis. The voltageactivated currents through calcium channels were analysed. GABA and the specific $G_{A B A}$ receptor agonist baclofen reduced the peak amplitude of inward $\mathrm{Ba}^{2+}$ current, as a robust alternate charge carrier through voltage-dependent $\mathrm{Ca}^{2+}$ channels. These effects were dose-dependent and reversible. $\mathrm{GABA}_{B}$ receptor antagonists, 2-hydroxysaclofen and $\delta$-amino-n-valeric acid, blocked the reduction of $\mathrm{Ba}^{2+}$ currents by GABA and baclofen, while bicuculline, a GABA receptor antagonist, had no blocking action. GABA and baclofen did not modify the dorsal sensory cell membrane conductance, indicating that they did not activate ligand-gated channels. However, GABA, but not baclofen, considerably increased membrane conductance and induced $\mathrm{Cl}^{-}$currents in isolated multipolar neurons (presumably interneurons and/or motoneurons). These findings suggest that GABA and baclofen action on lamprey dorsal sensory cells is mediated by $\mathrm{GABA}_{B}$ receptors. We concluded that GABA-mediated presynaptic inhibition of lamprey dorsal sensory cell fibers results from $\mathrm{GABA}_{B}$ receptor activation followed by a decrease of inward voltage-activated calcium currents. Appositions of GABA-immunoreactive boutons to horseradish peroxidase-labelled fibers from the dorsal root were observed at the ultrastructural level in the dorsal column using postembedding immunogold cytochemistry. It seems likely that these appositions represent the morphological substrate of dorsal sensory cell fiber presynaptic inhibition. In very rare cases, ultrastructural features were observed which could be interpreted as synaptic specializations between the GABA-immunoreactive boutons and the primary afferent fibers.
\end{abstract}

The extrasynaptic action of GABA as a basis of presynaptic inhibition of this population of primary afferent neurons is discussed.

\section{Keywords}

calcium channels, $\mathrm{GABA}_{B}$ receptors, presynaptic inhibition, GABA immunogold cytochemistry, lamprey spinal cord

\section{Abbreviations}

AVA, $\delta$-amino-n-valeric acid

$\mathrm{CP}$, creatine phosphate

DSC, dorsal sensory cell

EGTA, ethyleneglycolbis(aminoethylether)tetra-acetate

EPSP, excitatory postsynaptic potential

GABA-IR, GABA-immunoreactivity 
HEPES, $N$-2-hydroxyethylpiperazine- $N$ '-2-ethanesulfonic acid

HRP, horseradish peroxidase

TEA, tetramethylammonium

TTX, tetrodotoxin

Presynaptic inhibition plays an important role in the coordinating mechanisms of the spinal cord. It has been studied in detail in primary afferent fibers of the mammalian spinal cord, and its main features consist of (i) depression of the synaptic response of the postsynaptic neuron without modifying its membrane electrical parameters, (ii) primary afferent depolarization, and (iii) axoaxonal contacts with GABA used as a neurotransmitter.14, 29, 30, 45Presynaptic inhibition has also been found in the central nervous systems of invertebrates[25]and of several non-mammalian vertebrate groups: cyclostomes,[5]amphibians,34, 64and reptiles,[61]thus indicating the widespread character of this phenomenon.

Two mechanisms have been considered as the possible basis for GABA-mediated presynaptic inhibition. According to the first mechanism, presynaptic inhibition is the result of primary afferent depolarization produced by GABA.21, 29, 45, 58In this case, the action potential amplitude decreases as a result of membrane resistance shunting following $\mathrm{Cl}^{-}$current activation induced by GABA action on GABA receptors. [3]A second mechanism has been proposed recently. It has been shown that GABA application reduces voltage-dependent $\mathrm{Ca}^{2+}$ current through the nerve cell membrane.23, 26, 47In this case, the GABA effect is mediated by activation of $G A B A_{B}$ receptors of the presynaptic neuron membrane. Activation of $G A B A_{B}$ receptors reduces $\mathrm{Ca}^{2+}$ presynaptic influx and thereby decreases transmitter release from the presynaptic neuron.11, 13, 15, 28, 35, 39, 43, 46

Physiological studies of presynaptic inhibition in the lamprey have shown that it is an important component of the lamprey spinal cord locomotor system.3, 4, 5In the spinal cord in vitro preparation, GABA modified the frequency of ventral root motor bursts during fictive swimming without changing the electrical parameters of the motoneurons, and these effects persisted in the presence of bicuculline, a GABA receptor antagonist. [5]It has been concluded that in the lamprey spinal cord, GABA-mediated presynaptic inhibition occurs both in interneuron axons[3] and in primary afferent fibers.[17]GABA and the GABA ${ }_{B}$ receptor agonist reduced the monosynaptic excitatory postsynaptic potentials (EPSPs) produced in spinal interneurons by primary afferent neuron stimulation. Baclofen alone or GABA in the presence of bicuculline did not alter the input resistance or membrane potential of the postsynaptic neurons.[17]More recently, Matsushima et al.[47]demonstrated using single-electrode current-clamp and voltage-clamp that baclofen reduced the peak amplitude of $\mathrm{Ca}^{2+}\left(\mathrm{Ba}^{2+}\right)$ currents in lamprey spinal motoneurons and interneurons. However, direct analysis of GABAergic actions on the ionic currents of primary sensory neurons has been lacking.

Several studies have investigated the morphological substrates of primary afferent presynaptic inhibition in the lamprey. GABA-immunopositive terminals apposed to labelled axons of different functional properties have been demonstrated using light microscopy.[16]GABA-immunopositive terminals apposed to unlabelled fibers located in the dorsal columns and in the ventrolateral aspect of the spinal cord have also been observed using an ultrastructural analysis.[20]Recently, we have demonstrated that GABA-immunopositive cells are concentrated in the dorsal part of the lamprey spinal cord in the vicinity of primary afferent neurons, called dorsal sensory cells (DSCs), and their fibers.[8]

In the present work, we have obtained additional evidence concerning the ionic mechanisms and the morphological substrates of presynaptic inhibition in the lamprey spinal cord. Physiologically, we have demonstrated that GABA and baclofen modulate $\mathrm{Ba}^{2+}$ current in DSCs and that GABA receptor antagonists eliminate this effect. Morphologically using immunogold and horseradish peroxidase (HRP) methods, we have 
demonstrated that GABA-immunoreactive boutons make appositions to HRP-labelled fibers from the dorsal roots. Preliminary results have been reported previously.66, 67

\section{Experimental procedures}

\subsection{Physiological investigations}

Patch-clamp recordings in a whole-cell mode were performed on DSCs from the spinal cord of two lamprey species, Ichthyomyzon unicuspis (30-36 cm long) and Lampetra fluviatilis (29-33 cm long). Prior to the experiments, the animals were maintained in the laboratory in well-aerated tanks $\left(5-10^{\circ} \mathrm{C}\right)$. After anesthesia by immersion of the lamprey in tricaine, 3-4 cm lengths of spinal cord were removed and cut into 1-1.5-mm-long pieces. Individual cells were isolated by gentle trituration of these pieces of spinal cord after pretreatment with collagenase $(1.6 \mathrm{mg} / \mathrm{ml})$ and pronase $(0.5 \mathrm{mg} / \mathrm{ml})$. All procedures have been previously described in detail.[9]After dissociation, the cells were stored in a larger part of the recording chamber mounted on the stage of an inverted microscope (BIOLAM-1, LOMO, Russia). This larger part had a volume of $2 \mathrm{ml}$, and the volume of a well-isolated smaller part used for recordings was $0.5 \mathrm{ml}$. Solution $\mathrm{N}^{\circ} 1$, used for cell storage, consisted of the following (in mM): $\mathrm{NaCl}$ 92.0, $\mathrm{KCl}$ 2.5, $\mathrm{CaCl}_{2}$ 2.6, $\mathrm{MgCl}_{2}$ 2.4, $\mathrm{HEPES}$ (Na-salt) 20.0, EGTA 0.3, $\mathrm{NaHCO}_{3}$ 3.0, $\mathrm{NaH}_{2} \mathrm{PO}_{4} 0.75, \mathrm{Na}_{2} \mathrm{HPO}_{4} 0.25$, glucose 10.0, $\mathrm{pH}$ 7.4. Solution $\mathrm{N}^{\circ} 2$, used for recording calcium channel currents, consisted of the following (in $\mathrm{mM}$ ): $\mathrm{BaCl}_{2}$ 60.0, tetraethylammonium (TEA)-Cl 40.5, EGTA 0.1, $\mathrm{MgCl}_{2} 2.4$, HEPES 15.0 , tetrodotoxin (TTX) 0.001, pH 7.3. Both solutions were aerated with $\mathrm{O}_{2}$ and kept cooled $\left(10^{\circ} \mathrm{C}\right)$. Isolated DSCs could be clearly distinguished by their morphological features: they were bipolar cells with a round-shaped soma with a diameter of 35-60 $\mu \mathrm{m}$ and one or two branches from 30 up to $200 \mu \mathrm{m}$ length. Pipettes having tip diameters of 2-3 $\mu \mathrm{m}$ and resistances of 2-5 MOhms were pulled from Micro-Haematocrit capillary tubes (Labcraft Brand). The intrapipette solution consisted of the following (in $\mathrm{mM}$ ): Cs-glutamate 100.0, $\mathrm{CsMeSO}_{4}$ 20.0, $\mathrm{MgCl}_{2}$ 4.0, TEA-acetate 8.0, HEPES 10.0, EGTA 8.5, ATP 5.0, GTP 1.0, creatine phosphate (CP) 14.0, CP kinase $50 \mathrm{U} / \mathrm{ml}$, leupeptin 0.01 , glucose 10.0, pH 7.3. For a whole-cell recording the classical pressure rupture of the membrane inside the pipette and the equilibration of the intrapipette solution with the cytoplasm was used. After obtaining a whole-cell recording, the membrane potential was voltage-clamped at $-60 \mathrm{mV}$. The pipette with the attached cell was then moved to the smaller part of the recording chamber. Voltage-dependent inward current was evoked by a series of depolarizations from holding potentials of -60 or $-80 \mathrm{mV}$ up to $+30 \mathrm{mV}$ using $10 \mathrm{mV}$ steps of $500 \mathrm{~ms}$ duration. Macroscopic currents through calcium channels were isolated from voltage-dependent sodium and potassium channel currents as described by others.36, 48It is known that $\mathrm{Ba}^{2+}$ ions pass through the calcium channels and $\mathrm{Ba}^{2+}$ was used here as a charge carrier to provide a large, stable current and to remove $\mathrm{Ca}^{2+}$-dependent effects due to changes in intracellular $\mathrm{Ca}^{2+}$ concentration. This approach is widely used for isolating calcium channel currents.[10]Drugs were applied to within $200 \mu \mathrm{m}$ of the neuron using a Hamilton microsyringe. Whole-cell recordings were performed using the AXOPATCH-1D amplifier (Axon Instruments, U.S.A.) with the CV-4 headstage (Axon Instruments). The recordings were digitized with a DigiData-1200 (Axon Instruments) and stored on the hard disk of the computer IBM-PC-486. The program CLAMPEX of the PCLAMP 6.2 software package was used for data acquisition. For data analysis, the CLAMPFIT program of the same package was used. Leakage currents and capacitative currents were not subtracted. Membrane conductance was evaluated from the transmembrane current changes in response to a series of small voltage steps applied to the cell.

\subsection{Morphological investigations}

Six adult lampreys Lampetra fluviatilis 29-33-cm-long were used for postembedding immunogold cytochemistry with GABA antibodies. After anesthesia by immersion in tricaine, a 5-6 segment length of spinal cord from the dorsal fin region was dissected in aerated $\left(98 \% \mathrm{O}_{2}+2 \% \mathrm{CO}_{2}\right)$ physiological solution consisting of the following (in mM): $115 \mathrm{NaCl}, 0.8 \mathrm{NaH}_{2} \mathrm{PO}_{4}, 0.2 \mathrm{Na}_{2} \mathrm{HPO}_{4}, 2.0 \mathrm{KCl}, 2.0 \mathrm{CaCl}_{2}, 0.9 \mathrm{MgCl}_{2}, 8.0 \mathrm{NaHCO}_{3}, 5.5$ glucose, pH 7.3-7.4. 
HRP (Boehringer) was applied to the central stump of a cut dorsal root from a suction pipette using iontophoresis. The pipette contained a $5-10 \%$ solution of HRP in $0.1 \mathrm{M}$ phosphate buffer, $\mathrm{pH}$ 8.4. Positive current (3-5 $\mathrm{nA}$ ) was applied to the pipette during the first $0.5 \mathrm{~h}$, then the spinal cord piece was allowed to survive for 10-24 $\mathrm{h}$ with the HRP pipette remaining in place. The spinal cord piece was then fixed for 3-4 $\mathrm{h}$ with $1 \%$ paraformaldehyde and $2.5 \%$ glutaraldehyde in $0.1 \mathrm{M}$ phosphate buffer, $\mathrm{pH}$ 7.4. The spinal cord piece was processed for HRP with the Adams' technique,[1]cut into 2-mm-long pieces and Epon-embedded for conventional electron microscopy. Ultrathin sections were mounted on nickel grids and processed according to the standard immunogold procedure using polyclonal anti-GABA antisera, raised in rabbit (Immunotech) and diluted 1:2 000 in Tris-buffered saline ( $\mathrm{pH} \mathrm{7.6)}$ and goat anti-rabbit immunoglobulin coupled to colloidal gold particles, mean diameter $15 \mathrm{~nm}$ (Janssen) and diluted 1:75. Profiles were considered to be immunopositive if the density of gold particles exceeded that of the surrounding tissue by five-fold.

Control sections of lamprey spinal cord tissue, were reacted with fixative in the presence of GABA, l-glutamate, glycine, taurine, or l-aspartate, as described by Ottersen, [53] and then incubated with the anti-GABA antiserum. A high specificity of antiserum has been observed in most tests, though a weak cross-reactivity was found when the GABA antibody was used in the aspartate immunoconjugate. Another control test consisted of omitting the first antibody, which resulted in no labelling.

To evaluate the size and shape of synaptic vesicles, their diameters were measured and an index of vesicle ellipticity, $e$, was calculated according to the equation

$$
e=a^{2}-b^{2} a
$$

where $a$ and $b$ represent the longest and shortest diameters of the synaptic vesicles, respectively ( $0 \leq e<1$, for round-shaped vesicles $e=0$ ). [50]Values throughout the text are presented as mean \pm S.E.M.

\subsection{Materials}

$\delta$-Amino-n-valeric acid (AVA), I-aspartate, baclofen, (-)bicuculline methiodide, GABA, glycine, l-glutamate, muscimol, taurine, TEA, tricaine (MS 222), and TTX were obtained from Sigma Chemical Co., St. Louis, MO, U.S.A. 2-Hydroxysaclofen was obtained from Research Biochemicals International, Natick, MA, U.S.A.

\section{Results}

Fig. 1 is a schematic drawing of lamprey spinal cord sensory input. Primary afferent neurons of the lamprey spinal cord consist of two populations. One of them, as in other vertebrates, is the spinal ganglion cells, and the second consists of the DSCs which have a large soma (30-60 $\mu \mathrm{m})$ located in the dorsal part of the spinal cord just below the dorsal fiber column. The DSCs are homologous to the Rohon-Beard cells of fish and amphibians.19, 32, 52,57The dorsal roots are composed of both the central branches of the dorsal root ganglion cells and the peripheral branches of the DSCs. Ascending and descending axons of primary afferent neurons are located in the dorsal fiber column. 


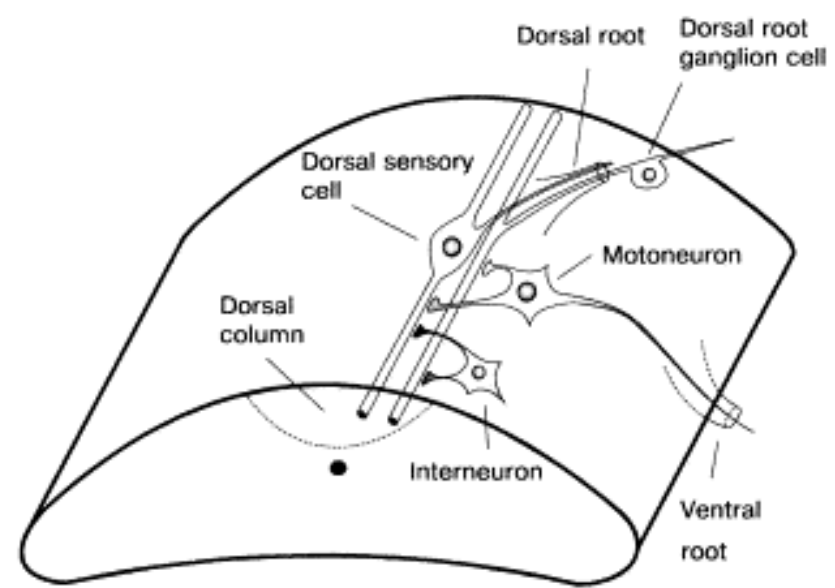

Fig. 1. Schematic drawing of a lamprey spinal cord segment illustrating some connections of two types of primary afferent neurons: dorsal sensory cells and dorsal root ganglion cells.

\subsection{Physiological investigations}

After dissociation, DSCs having processes from 40 to $200 \mu \mathrm{m}$ in length were chosen for investigation. The currents through the calcium channels were recorded in more than 200 DSCs and analysed in 59 DSCs

of Ichthyomyzon unicuspis and in 44 DSCs of Lampetra fluviatilis. These cells had membrane potentials from -32 to $-60 \mathrm{mV}$ (mean=-40.5 $\pm 9.1 \mathrm{mV}$ ) and generated $\mathrm{Na}^{+}$and $\mathrm{K}^{+}$currents with amplitudes up to $50 \mathrm{nA}$ in the normal solution $\left(N^{\circ} 1\right)$, when applying depolarizing voltage steps from the holding potential $-100 \mathrm{mV}$ up to $+30 \mathrm{mV}$ in a voltage-clamp mode (Fig. 2A, B). After performing this test to evaluate the condition of the cell, the pipette with the cell attached was then moved to the smaller part of the recording chamber, and the normal solution $\left(\mathrm{N}^{\circ} 1\right)$ was replaced by the calcium current solution ( $\left.N^{\circ} 2\right)$. After 2-3 min exposure to solution $N^{\circ} 2$, a series of depolarizing steps from -100 up to $+40 \mathrm{mV}$ evoked inward currents with kinetic parameters different than the $\mathrm{Na}^{+}$and $\mathrm{K}^{+}$currents recorded in the normal solution (Fig. 2C). Based on the current-voltage relationship, this current is likely to be a calcium channel current carried by $\mathrm{Ba}^{2+}$. The amplitude of the current was stable during $>30$ min perfusion with $1 \mu \mathrm{M} \mathrm{TTX}$, and it was blocked by the addition of $5 \mathrm{mM} \mathrm{CdCl}_{2}$ (Fig. 2D). It was the barium current in this case because $\mathrm{Ca}^{2+}$ was replaced with $\mathrm{Ba}^{2+}$ in the bath solution. Those cells maintaining stable parameters of $\mathrm{Ba}^{2+}$ current throughout the recording period were chosen for further analysis. The $\mathrm{Ba}^{2+}$ currents in DSCs from the two lamprey species used had similar values (see Table 1).

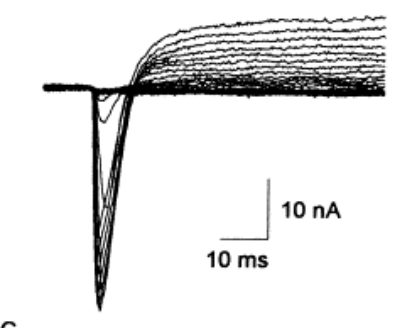

C

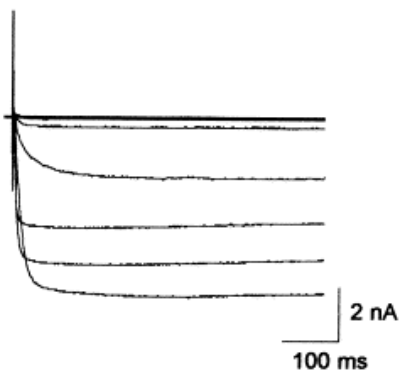

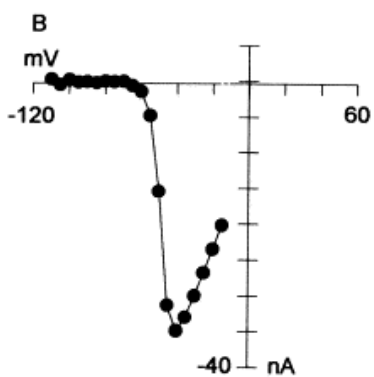

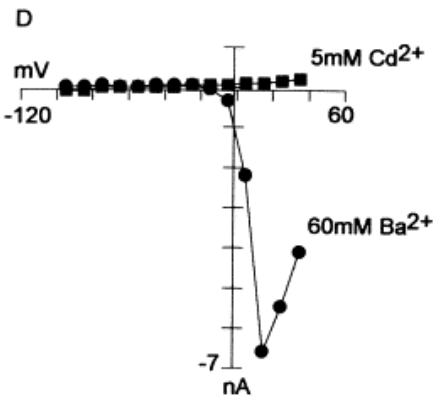


Fig. 2. Voltage-activated currents in an isolated dorsal sensory cell. Shifting the potential from $-100 \mathrm{mV}$ up to $+30 \mathrm{mV}$ produced $\mathrm{Na}^{+}$and $\mathrm{K}^{+}$currents through the membrane in solution $\mathrm{No} 1$ containing $\mathrm{Na}^{+}$and $\mathrm{K}^{+}$ions (A). The corresponding current-voltage curve is shown in B for the peak inward currents. When the same cell was bathed in solution No 2 containing no $\mathrm{Na}^{+}$and $\mathrm{K}^{+}$ions and with $\mathrm{Ba}^{2+}$ replacing $\mathrm{Ca}^{2+}$, shifting the potential from $-100 \mathrm{mV}$ up to $+40 \mathrm{mV}$ produced an inward current through the calcium channels (C). In (D) the current-voltage curves for the currents in $(\mathrm{C})$ are given before (round dots) and after block of the $\mathrm{Ba}^{2+}$ current by $5 \mathrm{mM}$ $\mathrm{Cd}^{2+}$ (square dots).

Table 1. Parameters of the barium current in dorsal sensory cells of two lamprey species

\begin{tabular}{|l|l|l|l|}
\hline Species & $\begin{array}{l}\text { Threshold potential of } \\
\mathrm{Ba}^{2+} \text { current }\end{array}$ & $\begin{array}{l}\text { Potential of peak } \\
\mathrm{Ba}^{2+} \text { current }\end{array}$ & $\begin{array}{l}\text { Mean peak value of } \\
\mathrm{Ba}^{2+} \text { current }\end{array}$ \\
\hline Ichthyomyzon unicuspis & -35 to $+5 \mathrm{mV}$ & -8 to $+30 \mathrm{mV}$ & $7.24 \pm 3.6 \mathrm{nA}(n=59)$ \\
\hline Lampetra fluviatilis & -30 to $-10 \mathrm{mV}$ & -20 to $+10 \mathrm{mV}$ & $8.48 \pm 6.0 \mathrm{nA}(n=44)$ \\
\hline
\end{tabular}

Addition of GABA to the perfusion solution always reduced the $\mathrm{Ba}^{2+}$ current amplitude. A typical effect of GABA on the $\mathrm{Ba}^{2+}$ current is illustrated in Fig. 3A. The GABA effect was dose-dependent and reversible. The minimal concentration of GABA required was $0.1 \mathrm{mM}$, while $10 \mathrm{mM} \mathrm{GABA}$ reduced the $\mathrm{Ba}^{2+}$ current by $50 \%$. We typically used moderate concentrations of GABA ( 1 and $4 \mathrm{mM}$ ) which permitted repeating the effect with serial reapplications and washes. The peak reduction of the $\mathrm{Ba}^{2+}$ current by GABA occurred within 1-2 min, and, therefore, all measurements of GABA effects were made $2 \mathrm{~min}$ after the addition of GABA. Application of $4 \mathrm{mM}$ GABA reduced the peak current amplitude by a mean value of $28.5 \pm 4.9 \%(n=45)$. After 2 min washing in GABAfree solution, the peak current amplitude recovered to $96.2 \pm 9.2 \%$ in both species $(n=45)$. GABA application did not change membrane conductance, nor did it cause opening of $\mathrm{Cl}^{-}$channels (see below).

Baclofen, a selective $G A B A_{B}$ receptor agonist, mimicked the GABA effect on the $\mathrm{Ba}^{2+}$ current in DSCs of both species (Fig. 3B). After 2 min perfusion with solution $\mathrm{N}^{\circ} 2$ containing $0.5 \mathrm{mM}$ baclofen, the peak amplitude of the $\mathrm{Ba}^{2+}$ current was reduced by $25.5 \% \pm 3.8 \%(n=30)$. After subsequent 2 min perfusion with baclofen-free solution, the $\mathrm{Ba}^{2+}$ current recovered its initial level (Fig. 3B).

GABA Baclofen
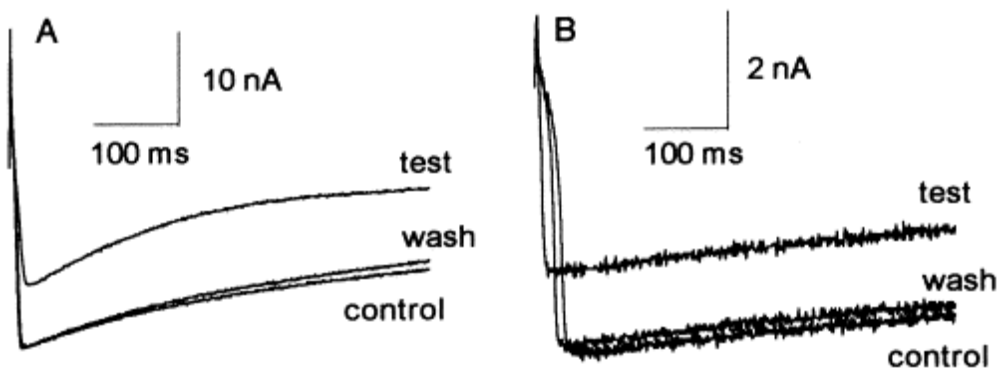

Fig. 3. Action of GABA and baclofen on the voltage-activated $\mathrm{Ba}^{2+}$ currents in an isolated dorsal sensory cell. Application of $4 \mathrm{mM} \mathrm{GABA}(\mathrm{A})$ and $0.5 \mathrm{mM}$ baclofen (B) to the bath solution reduced the peak amplitude of the voltage-activated $\mathrm{Ba}^{2+}$ currents by $28.5 \%$ and $25.5 \%$, respectively. After 2 min of wash out, the currents recovered $96.2 \%(A)$ and $89.1 \%(B)$ of their control levels.

To determine the pharmacological properties of the receptors activated by GABA and baclofen in DSCS membranes, specific antagonists of $G A B A_{A}$ and $G A B A_{B}$ receptors were used. In all seven DSCs tested, the GABA effect was not modified by a prior 1 min exposure of the cell to $0.1 \mathrm{mM}$ bicuculline, a $G A B A_{A}$ receptor antagonist (Fig. 4A,B). Similarly, in two DSCs, it was examined whether bicuculline antagonized the action of baclofen. The 
cells were preincubated for $1 \mathrm{~min}$ with $0.2 \mathrm{mM}$ bicuculline and then perfused with $0.1 \mathrm{mM}$ bicuculline plus $0.5 \mathrm{mM}$ baclofen. In the presence of baclofen and bicuculline the $\mathrm{Ba}^{2+}$ current decreased by $22 \%$ in one cell and by $30 \%$ in the second cell (not illustrated). After 2 min of wash out, the $\mathrm{Ba}^{2+}$ current recovered to 97 and $90 \%$ of control in the two cells, respectively. Thus, the effects of baclofen and GABA remained in the presence of the $\mathrm{GABA}_{A}$ receptor antagonist, bicuculline.

2-Hydroxysaclofen, an antagonist of $\mathrm{GABA}_{B}$ receptors,[41]was tested in four DSCs. First, the reduction of $\mathrm{Ba}^{2+}$ current by $0.5 \mathrm{mM}$ GABA was observed, then after a $10 \mathrm{~min}$ wash out, $0.1 \mathrm{mM}$ 2-hydroxysaclofen plus $0.5 \mathrm{mM}$ GABA accompanied by $0.1 \mathrm{mM}$ 2-hydroxysaclofen were added to the bath solution. In three cells, the $\mathrm{Ba}^{2+}$ current remained unchanged (Fig. $4 \mathrm{C}$ ), while in one cell it increased by $6 \%$.

A second $G A B A_{B}$ receptor antagonist, AVA,[59]was also tested. When applied alone, AVA did not modify the $\mathrm{Ba}^{2+}$ current in a concentration range of 0.14-1.4 mM. To determine the action of AVA on the baclofen effect, six cells were exposed for $1 \mathrm{~min}$ to $0.5 \mathrm{mM}$ AVA. Then they were perfused for $2 \mathrm{~min}$ with $0.2 \mathrm{mM}$ AVA plus $0.5 \mathrm{mM}$ baclofen. In five cells, the $\mathrm{Ba}^{2+}$ currents were not modified (Fig. 4D), while in one cell the $\mathrm{Ba}^{2+}$ current was decreased by $4 \%$. Thus, the actions of GABA and baclofen on the $\mathrm{Ba}^{2+}$ currents were blocked by $\mathrm{GABA}_{\mathrm{B}}$ receptor antagonists.
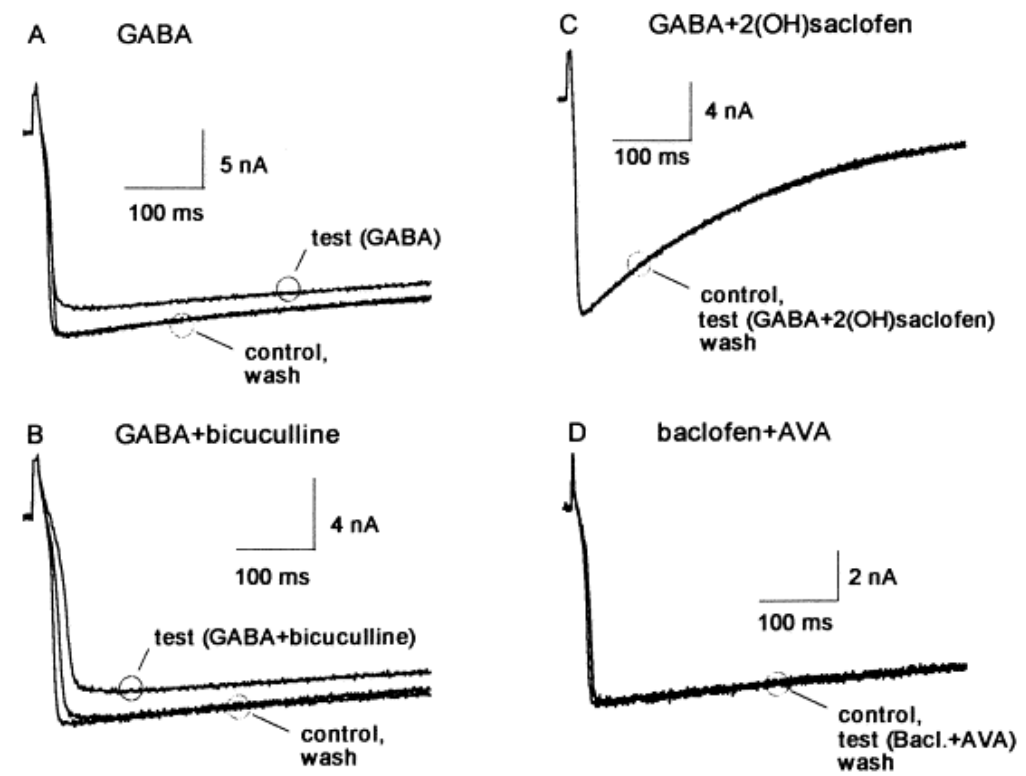

Fig. 4. Influences of GABA receptor antagonists on the GABA and baclofen reductions of the $\mathrm{Ba}^{2+}$ current. In an isolated dorsal sensory cell, GABA reduced the $\mathrm{Ba}^{2+}$ current by $13.2 \%(\mathrm{~A})$. Bicuculline $(0.2 \mathrm{mM})$, a $\mathrm{GABA}_{\mathrm{A}}$ receptor antagonist, did not modify the GABA effect in the same cell (B). 2-Hydroxysaclofen (0.1 mM) and AVA (0.2 mM), $G_{B A A_{B}}$ receptor antagonists, blocked the GABA and baclofen reductions of the $\mathrm{Ba}^{2+}$ current in dorsal sensory cells ( $C$ and $D$, respectively). Controls and tests represent the currents recorded before and after antagonist application, respectively.

Muscimol (0.5 mM), a GABA receptor agonist and a weak $\mathrm{GABA}_{B}$ agonist,12, 62decreased the peak amplitude of the $\mathrm{Ba}^{2+}$ current by $13 \pm 2.6 \%(n=8)$.

Glycine and taurine induced $\mathrm{Cl}^{-}$currents and have been shown to act on both GABA and glycine receptors in isolated multipolar cells of adult lampreys. The action of glycine $(1 \mathrm{mM})$ and taurine $(5 \mathrm{mM})$ was tested now on the $\mathrm{Ba}^{2+}$ current in eight DSCs from I. unicuspis and five DSCs from L. fluviatilis. Neither glycine nor taurine affected the $\mathrm{Ba}^{2+}$ currents. 
To measure changes in membrane conductance with application of GABA and baclofen, a passive current was induced through the membrane in a voltage-clamp mode using depolarizing voltage pulses of $20 \mathrm{mV}, 100 \mathrm{~ms}$ in duration, and with intervals of $200 \mathrm{~ms}$ for $15 \mathrm{~s}$ (Fig. 5). In all eight DSCs tested, the conductance did not change after application of 0.5-1.0 mM baclofen or 1-4 mM GABA (Fig. 5A,1,2), indicating that neither baclofen nor GABA activated ligand-gated channels. Consistent with this conclusion, GABA and baclofen application did not induce any additional currents in the same DSCs (Fig. 5A,4,5). However, it has been shown that activation of $\mathrm{GABA}_{\mathrm{A}}$ receptors induces $\mathrm{Cl}^{-}$current and increases the membrane conductance in giant interneurons of the lamprey spinal cord.[37]To compare GABA and baclofen effects in different populations of lamprey spinal cord neurons, we performed the same experiments in isolated multipolar neurons (presumably interneurons and/or motoneurons). As shown in Fig. 5B, baclofen did not produce any membrane conductance change (Fig. 5B2), while GABA considerably increased the membrane conductance and induced a $\mathrm{Cl}^{-}$current (Fig. 5B1,4).

A

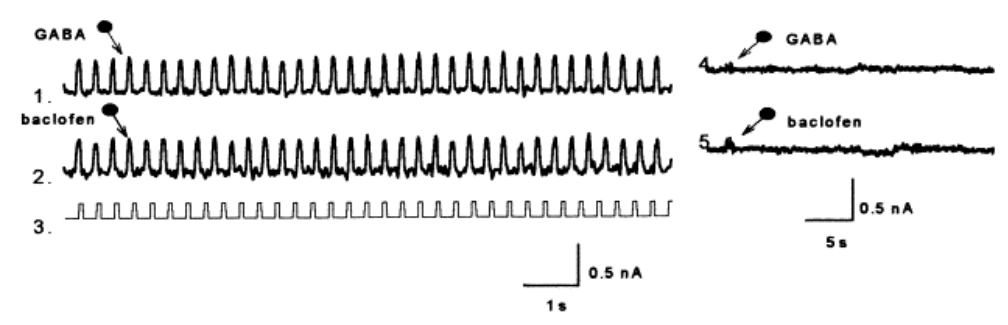

B

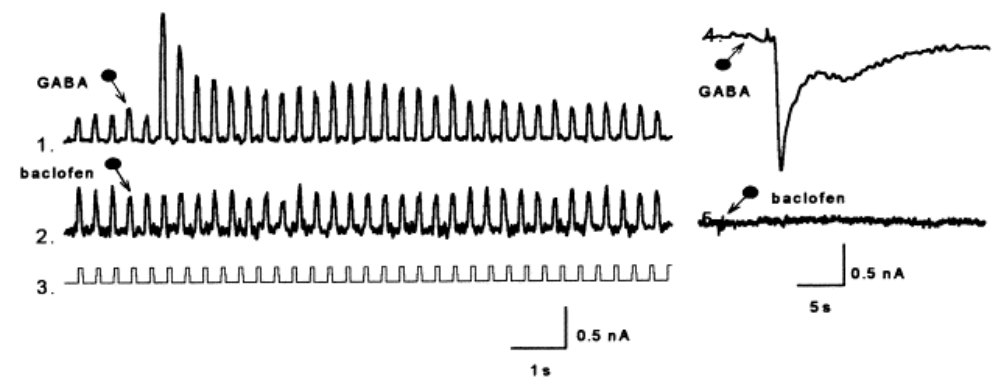

Fig. 5. Effects of GABA and baclofen on the membrane conductance of spinal neurons. (A) In a dorsal sensory cell, the amplitudes of passive currents evoked by a series of voltage pulses (3) were not modified by $4 \mathrm{mM}$ GABA (1) or by $1 \mathrm{mM}$ baclofen (2) applications. Neither GABA nor baclofen induced currents in the same cells in a voltage-clamp mode (4 and 5, respectively). (B) In a multipolar neuron (presumably an interneuron or a motoneuron), the amplitudes of passive currents increased after GABA application (1) indicating an increased membrane conductance, but the current amplitudes were not changed after baclofen application (2). Voltage pulses in $\mathrm{A}$ and $\mathrm{B}$ were $20 \mathrm{mV}$ in amplitude and $100 \mathrm{~ms}$ in duration (3). GABA, but not baclofen, evoked $\mathrm{Cl}-$ current in the same multipolar neuron ( 4 and 5 , respectively). The moment of drug application is marked by arrows.

\subsection{Morphological investigations}

After HRP application to the central stump of the cut dorsal root, the labelled fibers could be followed in semithin transverse sections for several spinal segments in both the rostral and the caudal directions. Labelled fibers were found ipsilaterally in the lateral zone of the dorsal column forming a vertically-oriented band extending from the entrance of the dorsal root to the ventral limit of the dorsal column. Several DSCs were also labelled. They were characteristically localized in the zone between the dorsal column and the large reticulospinal Müller axons and they had a rather regular round shape with no dendrites. In transverse ultrathin sections at the electron microscopic level, the primary afferent fiber profiles labelled with HRP could be easily 
distinguished (Fig. 6A,C). After GABA immunocytochemical processing, these fibers never produced any GABAimmunoreactivity (GABA-IR). Labelled primary afferent fibers made conventional synapses onto unidentified dendrites. These synapses were asymmetric, and contained round synaptic vesicles with a maximum diameter that ranged from 32 to $61 \mathrm{~nm}$ ( $m e a n=45.8 \pm 6.3 \mathrm{~nm}, n=150$ ) and with an index of ellipticity of $e=0.53$.

Postsynaptic dendritic profiles were usually GABA-immunonegative, but some GABA-immunopositive postsynaptic dendrites were observed. In ultrathin sections obtained from the spinal cords of six animals, we photographed 62 synapses formed by primary afferent fibers onto postsynaptic dendrites. GABA-ir boutons containing synaptic vesicles were found in close proximity to $66 \%$ of these synapses (Fig. 6). The directly apposed primary afferent fiber and the GABA-IR bouton profile were not separated by any other profiles. The apposed GABA-IR boutons often made symmetric synapses onto the same dendritic profile that was contacted by the primary afferent fiber, thus forming a triad. Synaptic vesicles of the GABA-IR boutons were usually clustered over the presynaptic membrane, but were also often found to be associated with the membrane apposed to the afferent fiber. The vesicles of these GABA-IR boutons had a shape and diameter similar to those observed in the primary afferent fibers. Their maximum diameter ranged from 31 to $55 \mathrm{~nm}$ ( $m e a n=46.7 \pm 5.6 \mathrm{~nm}, n=150$ ) and had an index of ellipticity of $e=0.56$. In most cases the apposition between the GABA-IR bouton and the afferent axon displayed no synaptic specializations. Only in two cases of these appositions were observed ultrastructural features that could be interpreted as synaptic-like specializations. In these cases, small densities were distinguished in the presynaptic and postsynaptic areas of the apposed zones, and the synaptic vesicles were associated with the presynaptic membranes (Fig. 7).

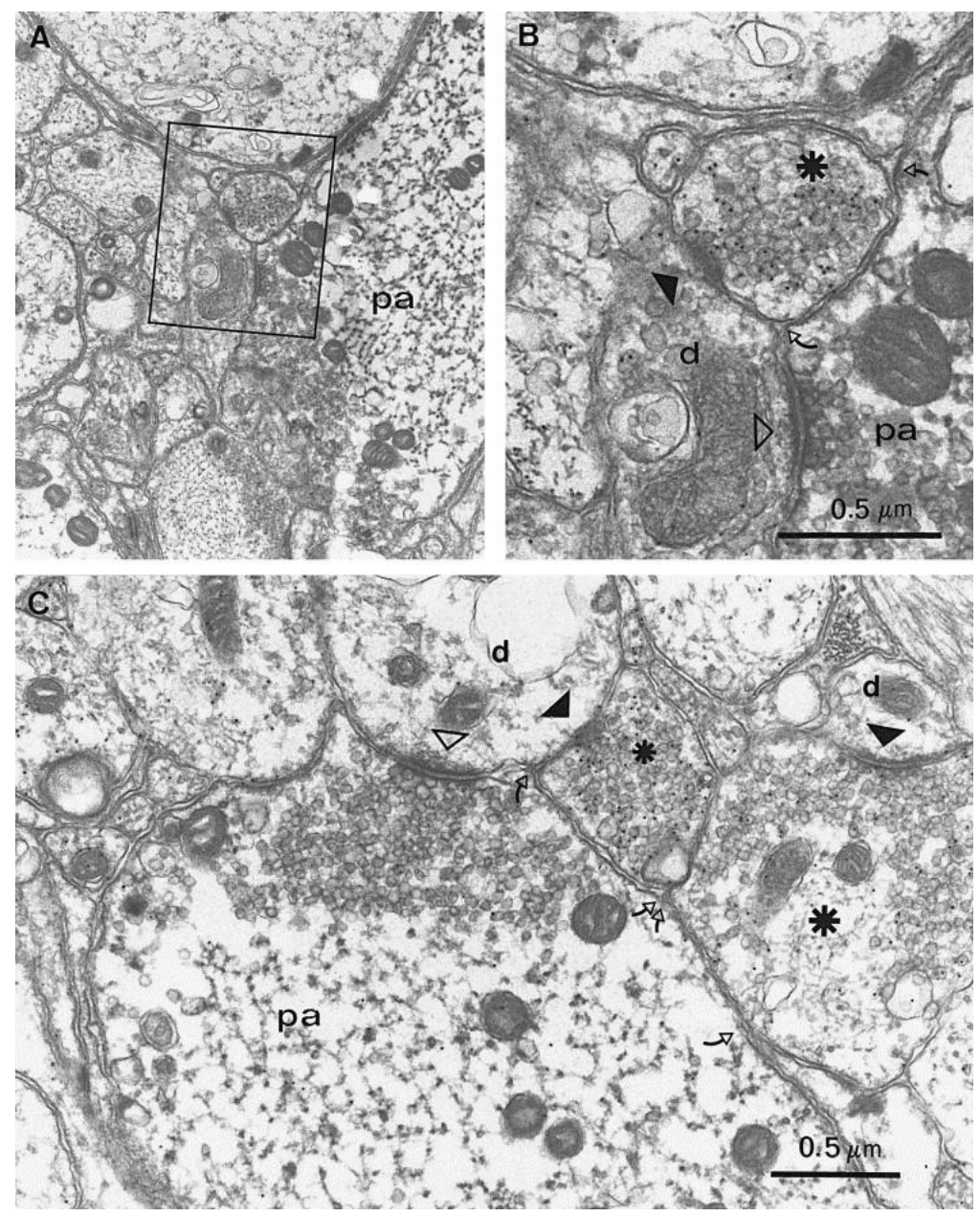

Fig. 6. Apposition of GABA-immunoreactive boutons and HRP-labelled primary afferent fibers (pa). Two examples (A and C). (B) High power view of the boxed area in (A). Apposed GABA-immunoreactive boutons are indicated by asterisks. Appositions are delimited by unfilled arrows. Synapses of primary afferent fibers with 
non-identified dendrites (d) are indicated by unfilled arrowheads, and synapses of GABA-immunopositive boutons with non-identified dendrites are indicated by filled arrowheads.

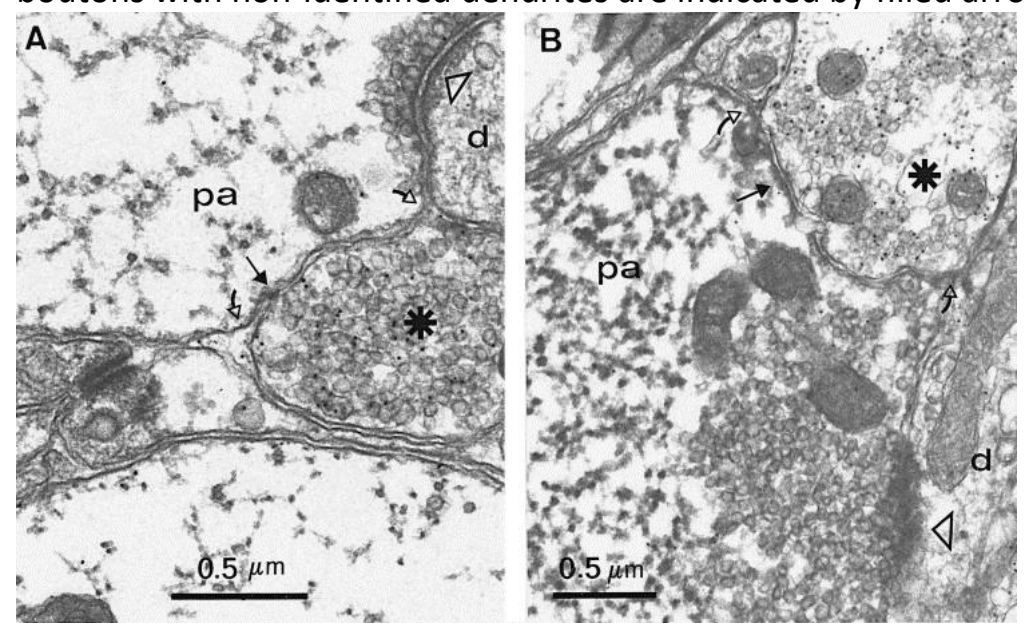

Fig. 7. Two cases of presumed synaptic-like specializations in the apposed zone of primary afferent fiber (pa) and GABA-immunoreactive bouton (A, B). GABA-immunoreactive boutons are indicated by asterisks. Appositions are delimited by unfilled arrows. Filled arrows indicate ultrastructural features which could be interpreted as synaptic-like specializations. HRP-labelled primary afferent fibers make synapses (unfilled arrowheads) with nonidentified dendrites (d).

\section{Discussion}

\subsection{Physiological investigations}

In the present work, we studied the $\mathrm{Ca}^{2+}$ channel currents in DSCs that possessed axonal processes of 40 to $200 \mu \mathrm{m}$ in length after enzymatic dissociation. While we cannot say with certainty how much the processes themselves contributed to the results observed here, we suggest that they were likely to be within the voltageclamped zone. In our experiments, the pipette position in different cells varied from the centre of DSC soma to the initial region of a DSC process, but the effects of GABA agonists on $\mathrm{Ca}^{2+}$ channel currents did not depend on the micropipette position. This observation supports the idea that the soma and the proximal axonal processes exhibit similar GABAergic mechanisms and may thus reflect GABAergic mechanisms in more distal axonal processes. It was shown recently that GABA-immunopositive terminals were located both in close apposition to the DSC somata and their processes.[8]Therefore, it is quite possible that GABA receptors are distributed both in the soma and fiber membrane. It seems likely that there are no $G_{A B A}$ receptors in the DSC membrane because $\mathrm{Cl}^{-}$currents were not induced in DSCs by GABA application.

The $\mathrm{Ca}^{2+}$ channel current was isolated in more than 200 DSCs obtained from two lamprey species, Ichthyomyzon unicuspis and Lampetra fluviatilis. Judging by the threshold potentials of calcium channel activation in different DSCs, the calcium channels are not uniform and can be subdivided into several types[9] as in other vertebrate neurons.42, 48To ensure that all types of $\mathrm{Ca}^{2+}$ channels could be activated, the holding potential was maintained in our experiments at the level of -100 or $-80 \mathrm{mV}$. Under these conditions, the threshold potentials of $\mathrm{Ca}^{2+}$ channel currents were close to $(-35 \mathrm{mV})$ or varied between $-10 \mathrm{mV}$ and $+5 \mathrm{mV}$. Our results are in accordance with data on calcium channel properties obtained in DSCs of the isolated lamprey spinal cord.18, 47Christenson et al.[18]reported that the presence of low-voltage-activated calcium channels is characteristic of touch-activated DSCs, but not of pressure-activated DSCs of the lamprey spinal cord. They gave the fraction of low-voltage-activated DSCs as three out of fifteen total DSCs. 
In the present study, GABA reduced the peak amplitude of $\mathrm{Ca}^{2+}$ channel currents in isolated DSCs. In the present investigation, it was also observed that the GABA effect was mimicked by baclofen, a GABA $A_{B}$ receptor agonist. The baclofen effect was reversible and was abolished by $G A B A_{B}$ receptor antagonists. Thus, the evidence here strongly suggests that the GABA and baclofen effect on lamprey DSCs is mediated by GABA $A_{B}$ receptors and that it acts to reduce the peak amplitude of voltage-activated calcium current. This is in accordance with the data obtained by Matsushima et al.,[47]who found using single-electrode voltage-clamp recordings in the isolated lamprey spinal cord that baclofen reduced the peak amplitude of calcium currents in both low- and highthreshold $\mathrm{Ca}^{2+}$ channels in motoneurons and interneurons. The involvement of $\mathrm{GABA}_{B}$ receptor activation in the mediation of presynaptic inhibition has been previously demonstrated in the isolated spinal cord of the lamprey.4, 17These authors demonstrated additionally that these $\mathrm{GABA}_{\mathrm{B}}$ effects are mediated by G-proteins.

Therefore, taken together, the evidence suggests that GABA-mediated presynaptic inhibition of lamprey DSC fibers results from $\mathrm{GABA}_{B}$ receptor activation followed by a decrease of inward voltage-activated calcium currents. The inhibition of calcium entrance into the axonal presynaptic zone results in a decrease of neurotransmitter release in many other preparations.13, 22, 40, 46Therefore, glutamate release from sensory afferent fiber synapses terminating on spinal interneurons and motoneurons will be decreased.

According to the data obtained in the present work, GABA and baclofen application did not change the membrane conductance of the DSCs. In addition, GABA receptor antagonists did not modify the GABA effect on the DSCs. This lack of GABA $A_{A}$ effect in the isolated DSCs (Fig. 5A,4) can not be attributed to the enzyme treatments used for dissociation because under the same conditions isolated multipolar cells displayed robust $\mathrm{GABA}_{\mathrm{A}}$ effects (Fig. 5B,4). It seems likely, therefore, that the DSC membrane possesses no or few $G A B A_{A}$ receptors and that there may be different $G A B A_{A}$ and $G A B A_{B}$ receptor distributions in different neuron populations of the lamprey spinal cord.

\subsection{Morphological investigations}

Six amino acid-protein complexes fixed with glutaraldehyde were used for testing the specificity of the antiGABA antibody. The control experiments showed a selective labelling of GABA-containing conjugate. The other amino acids expressed no immunogold labelling or only weak labelling in the case of aspartate-containing conjugate. This allows us to conclude that the antibody detects GABA in the tissue with sufficient selectivity. In our experimental material, immunolabelling was clustered over profiles containing synaptic vesicles. The ultrastructure of these synapses differed from that of primary afferent synapses. Synapses made by the immunolabelled boutons onto unidentified dendrites were symmetric while the primary afferent fibers established asymmetric synapses which are known to be glutamatergic.[17]Therefore, the ultrastructure of these GABA-immunolabelled boutons alone suggests that they belong to inhibitory neurons. It has been proposed that the density of gold particles reflects the antigen concentration. [54]Since the density of gold particles over the boutons exceeded the background by more than five times, it is concluded that there was a high concentration of GABA in the immunolabelled boutons.

The arrangement of GABA-IR boutons apposed to HRP-labelled fibers from the dorsal root and located in the lamprey dorsal column, which was observed in our experiments, coincides on the whole with the descriptions of Christenson et al.[20]In that work, GABA-IR terminals were found to make appositions with unlabelled axons located in the dorsal column. These authors concluded that axons with apposed GABA-IR profiles were primary afferent axons because most of the axons of the dorsal column are probably derived from primary sensory neurons.19, 570ur findings made with HRP-labelled primary afferent fibers confirm this conclusion.

In few cases, we found ultrastructural features which could be interpreted as synaptic specializations between the GABA-IR boutons and the primary afferent fibers. This observation is in agreement with the previous finding that only $2-3 \%$ of apposed GABA-IR terminals and GABA-negative axons could be suggested to make a 
synapse.[20]It seems unlikely that GABA release in these rare synapses could be sufficient to produce the total inhibitory effect on the primary afferent axons. Rather the GABA effect on the primary afferent axon is extrasynaptic. The lack of true axoaxonal synapses in lamprey primary afferent terminal therefore suggests that GABA is acting extrasynaptically in this model of presynaptic inhibition in lamprey and it is also consistent with the absence of $\mathrm{GABA}_{A}$ receptors in dorsal sensory cells. Stuart and Redman[63]also suggested that in cat primary afferents, (-)-baclofen-activated receptors are predominantly extrasynaptic.

It is possible to hypothesize that GABA reaches the extrasynaptic $\mathrm{GABA}_{\mathrm{B}}$ receptors of the primary afferent axon membrane by two different routes. In the first hypothesized route, GABA could be released non-synaptically from the apposed bouton, and in the second route, GABA could diffuse from neighbouring axodendritic synapses of the GABA-IR terminals (Fig. 8). Non-synaptic release of GABA from GABA-containing axon terminals was proposed by Christenson et al.[20] to be a way of GABA access to the primary afferent fibers in this neuronal circuit of the lamprey. Non-synaptic release of other neurotransmitters and their actions on distant receptors has been previously discussed.2, 7, 33The long extent of the appositions and the frequently observed clustering of synaptic vesicles near the apposed neuronal membrane can be considered as an arrangement favourable to this mode of GABA action. Under conditions of high sustained activity, it has been shown that the GABAtransporter may function in reverse, thereby increasing extracellular levels of GABA.[56]Carrier-mediated release of GABA from neurons and glial cells has been demonstrated in different experimental conditions.27, 44Carrier-mediated release could therefore increase the level of GABA around the primary afferent fibers in the extrasynaptic zone.

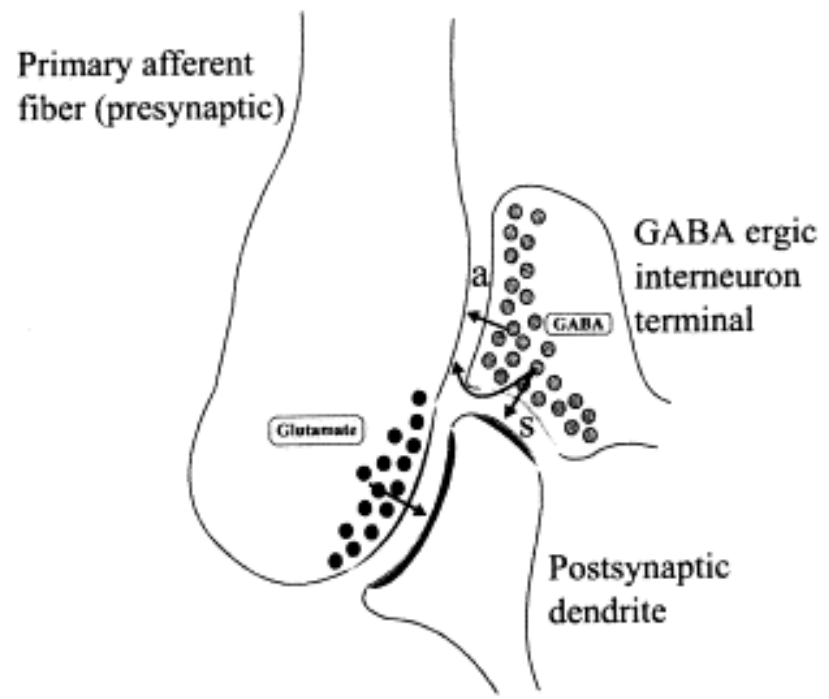

Fig. 8. Schematic drawing of the neuronal circuitry providing presynaptic inhibition of lamprey spinal cord primary afferents. GABA presumably acts on the extrasynaptic $G A B A_{B}$ receptors located on the primary afferent fiber surface in the apposition zone (a). GABA could reach these receptors by diffusing from neighbouring synaptic cleft (s) or by being released non-synaptically.

However, there are also arguments in favour of the second hypothesis regarding the route for GABA to reach extrasynaptic $G_{A B A_{B}}$ receptors. The lateral diffusion of transmitter from one discrete postsynaptic domain to another has been shown in neighbouring glycinergic synapses of the Mauthner cell.[31]In addition, there is experimental evidence suggesting that during increased synaptic release, only part of the GABA can be removed by re-uptake. Under these conditions, GABA would diffuse to extrasynaptic sites and act upon extrasynaptic receptors (for review see [60]). Experimental evidence for distant actions of GABA has been obtained in the neuronal circuits of the hippocampus.[38]Stimulation of one bundle of afferent fibers in the stratum radiatum region of CA1 caused short-lasting, heterosynaptic depression of excitatory transmission in an independent, 
overlapping set of inputs. These authors concluded that GABA released from conventional synapses spilled over and acted as a diffuse signal onto nearby (within micrometers) excitatory synaptic terminals. This conclusion was supported by the observation that inhibition of GABA re-uptake enhanced the presynaptic inhibitory effect of GABA in this paradigm.[38]Diffusion of GABA from GABAergic synapses to neighbouring glutamate-containing terminals in the mammalian brain and the subsequent action of GABA on GABA ${ }_{B}$ receptors have already been discussed.[51]Our data do not contain sufficient evidence permitting exclusion of either hypothesis, but it seems likely that the ultrastructural interrelations observed in the lamprey spinal cord could provide the morphological substrate for both mechanisms of GABA actions on the primary afferent fiber: the effect of GABA released nonsynaptically or diffusing from neighbouring conventional synapses.

\section{Conclusion}

The data concerning the physiological and morphological basis of primary afferent presynaptic inhibition in lampreys and in mammals do not coincide in all details. It seems likely that in lamprey, presynaptic inhibition of primary afferents is mediated by $\mathrm{GABA}_{B}$ receptors, and $\mathrm{GABA}_{A}$ receptors seem to be absent in the lamprey primary afferent neurons (at least in one class of primary afferents, the dorsal sensory cells). In mammals, however, primary afferent presynaptic inhibition is mediated by $G_{A B A_{A}}$ receptors $55,63,65$ or both $\mathrm{GABA}_{A}$ and $G_{A B A_{B}}$ receptors. [24]Synaptic contacts of GABA-containing boutons and primary afferent fibers have been described in mammals,6, 49while in lamprey such synapses are extremely rare if not absent at all (Christenson et al.[20]and the present investigation). This variance may be explained by species differences. It can also be suggested that the difference in GABA receptor types observed in primary afferent neurons of lampreys versus mammals may be due to the fact that we have studied GABA receptors only in the dorsal sensory cells, which represent only one class of lamprey primary afferent neurons and are not present in mammals. It has been shown that $\mathrm{GABA}_{A}$ receptors mediate presynaptic inhibition in other neurons of the lamprey spinal cord.[3]

\section{Acknowledgements}

We thank D. Le Cren and B. Riabov for their photographic and technical assistance, respectively. This research was supported by NIH Fogarty International Research Collaboration Award (USA, Grant No R03 TW00245-01), by Russian Foundation of Basic Research (Grants N 96-04-50611 and N 96-15-97650) and by INSERM France-CEI Collaboration Program.

\section{References}

1 J.C. Adams. Heavy metal intensification of DAB-based HRP reaction product. J. Histochem. Cytochem., 29 (1981), p. 775

2 Agnati L. F. and Fuxe K. (1996) The impact of histological techniques in revealing brain function. Volume transmission: from fluorescence histochemistry to confocal laser microscopy. In Molecular Mechanisms of Neuronal Communication (eds Fuxe K., Hökfelt T., Olson L., Ottoson D,. Dahlström A. and Björklund A.), Vol. 68, pp. 251-277. Wenner-Gren International Series, Pergamon, Oxford, New York, Tokyo.

3 S. Alford, J. Christenson, S. Grillner. Presynaptic $\mathrm{GABA}_{A}$ and $\mathrm{GABA}_{B}$ receptor-mediated phasic modulation in axons of spinal motor interneurons. Eur. J. Neurosci., 3 (1991), pp. 107-117

4 S. Alford, S. Grillner. The involvement of $\mathrm{GABA}_{B}$ receptors and coupled G-proteins in spinal GABAergic presynaptic inhibition. J. Neurosci., 11 (1991), pp. 3718-3726

5 S. Alford, K.A. Sigvardt, T.L. Williams. GABAergic control of rhythmic activity in the presence of strychnine in the lamprey spinal cord. Brain Res., 506 (1990), pp. 303-306

6 R.P. Barber, J.E. Vaughn, K. Saito, B.J. McLaughlin, E. Roberts. GABAergic terminals are presynaptic to primary afferent terminals in the substantia gelatinosa of the rat spinal cord. Brain Res., 141 (1978), pp. 35-55 
7 B. Barbour, M. Häusser. Intersynaptic diffusion of neurotransmitter. Trends Neurosci., 20 (1997), pp. 377-384 8 I.V. Batueva, E.I. Suderevskaya, N.P. Vesselkin, J. Pierre, J. Repérant. Localisation of GABA-immunopositive cells in the river lamprey spinal cord. J. Hirnforsch., 6 (1990), pp. 739-745

9 I.V. Batueva, E.A. Tsvetkov, J.T. Buchanan, N.P. Vesselkin. The study of potential-activated currents in the isolated neurons of the spinal cord of river lamprey Lampetra fluviatilis. Zh. Evol. Biokhim. $\mathrm{i}$ Fiziol., 32 (1996), pp. 267-283. (in Russian)

10 B.P. Bean. Whole-cell recording of calcium channel currents. Meth. Enzym., 207 (1992), pp. 181-193

11 N.G. Bowery, A. Doble, D.R. Hill, A.L. Hudson, J.S. Shaw, M.J. Turnbull, R. Warrington. Bicuculline-insensitive GABA receptors on peripheral autonomic nerve terminals. Eur. J. Pharmac., 71 (1981), pp. 53-70

12 N.G. Bowery, D.R. Hill, A.L. Hudson. Characteristics of $\mathrm{GABA}_{B}$ receptor binding sites on rat whole brain synaptic membranes. Br. J. Pharmac., 78 (1983), pp. 191-206

13 N.G. Bowery, D.R. Hill, A.L. Hudson, A. Doble, D.N. Middlemiss, J.S. Shaw, M.J. Turnbull. (-)-Baclofen decreases neurotransmitter release in the mammalian CNS by an action at a novel GABA receptor. Nature, 283 (1980), pp. 92-94

14 D. Carpenter, I. Engberg, A. Lundberg. Presynaptic inhibition in the lumbar cord evoked from the brain stem. Experientia, 18 (1962), p. 450

$15 \mathrm{E}$. Cherubini, A. North. Inhibition of calcium spikes and transmitter release by $\boldsymbol{\gamma}$-aminobutyric acid in the guinea-pig myenteric plexus. Br. J. Pharmac., 82 (1984), pp. 101-105

16 J. Christenson, F. Bongianni, S. Grillner, T. Hökfelt. Putative GABAergic input to axons of spinal interneurons and primary sensory neurons in the lamprey spinal cord as shown by intracellular Lucifer yellow and GABA immunohistochemistry. Brain Res., 538 (1991), pp. 313-318

$17 \mathrm{~J}$. Christenson, S. Grillner. Primary afferents evoke excitatory amino acid receptor-mediated EPSPs that are modulated by presynaptic GABA ${ }_{B}$ receptors in lamprey. J. Neurophysiol., 66 (1991), pp. 2141-2149

18 J. Christenson, R.H. Hill, F. Bongianni, S. Grillner. Presence of low voltage activated calcium channels distinguishes touch from pressure sensory neurons in the lamprey spinal cord. Brain Res., 608 (1993), pp. 58-66

19 J. Christenson, P.Å. Lagerbäck, S. Grillner. The dorsal cell, one class of primary sensory neuron in the lamprey spinal cord. II. A light and electron microscopical study. Brain Res., 440 (1988), pp. 9-17

20 J. Christenson, O. Shupliakov, S. Cullheim, S. Grillner. Possible morphological substrates for GABA-mediated presynaptic inhibition in the lamprey spinal cord. J. comp. Neurol., 328 (1993), pp. 463-472

21 D.R. Curtis, D. Lodge, S.J. Brand. GABA and spinal afferent terminal excitability in the cat. Brain Res., 130 (1977), pp. 360-363

$22 \mathrm{~J}$. Davies. Selective depression of synaptic excitation in cat spinal neurones by baclofen: an iontophoretic study. Br. J. Pharmac., 72 (1981), pp. 373-384

23 R.A. Deisz, H.D. Lux. $\boldsymbol{y}$-Aminobutyric acid-induced depression of calcium currents of chick sensory neurons. Neurosci. Lett., 56 (1985), pp. 205-210

24 M. Desarmenien, P. Feltz, G. Occhipinti, F. Santangelo, R. Schlichter. Coexistence of GABA $A_{A}$ and GABA $_{B}$ receptors on $A$ delta and C primary afferents. Br. J. Pharmac., 81 (1984), pp. 327-333

25 J. Dudel, S.W. Kuffler. Presynaptic inhibition at the crayfish neuromuscular junction. J. Physiol., Lond., 155 (1961), pp. 537-557

26 K. Dunlap, G.D. Fischbach. Neurotransmitters decrease the calcium conductance activated by depolarization of embryonic chick sensory neurons. J. Physiol., Lond., 317 (1981), pp. 519-535

27 M.J. During, K.M. Ryder, D.D. Spencer. Hippocampal GABA transporter function in temporal-lobe epilepsy. Nature, 376 (1995), pp. 174-177

28 P. Dutar, R.A. Nicoll. A physiological role for $\mathrm{GABA}_{B}$ receptors in central nervous system. Nature, 332 (1988), pp. 156-158 
29 J.C. Eccles, F. Marni, W.D. Willis. Depolarization of central terminals of group I afferent fibres from muscle. J. Physiol., Lond., 160 (1962), pp. 62-93

30 J.C. Eccles, R. Schmidt, W.D. Willis. Pharmacological studies on presynaptic inhibition. J. Physiol., Lond., 168 (1963), pp. 500-530

31 D.S. Faber, H. Korn. Synergism at central synapses due to lateral diffusion of transmitter. Proc. natn. Acad. Sci. U.S.A., 85 (1988), pp. 8708-8712

32 Z. Freud. Über spinalganglien und rückenmark des Petromyzon. Sber. Akad. Wiss. Wien, 75 (1878), pp. 81167

33 Fuxe K. and Agnati L. F. (1991) Two principal modes of electrochemical communication in the brain: volume versus wiring transmission. In Volume Transmission in the Brain: Novel Mechanisms for Neural Transmission. Advances in Neuroscience (eds Fuxe K. and Agnati L.), pp. 1-9. Raven, New York.

34 S. Glusman, H. Vázguez, P. Rudomín. Possible cor35 relation between primary afferent depolarization (PAD) and ultrastructure in the frog spinal cord. Physiologist, Wash., 15 (1972), p. 142

35 J.A. Gray, A.R. Green. GABA ${ }_{B}$-receptor mediated inhibition of potassium-evoked release of endogenous 5hydroxytryptamine from mouse frontal cortex. Br. J. Pharmac., 91 (1987), pp. 517-522

$36 \mathrm{~S}$. Hagiwara, H. Ohmori. Studies of calcium channels in rat clonal pituitary cells with patch electrode voltage clamp. J. Physiol., Lond., 331 (1982), pp. 231-252

$37 \mathrm{~S}$. Homma, C.M. Rovainen. Conductance increases produced by glycine and $\boldsymbol{\gamma}$-aminobutyric acid in lamprey interneurons. J. Physiol., Lond., 279 (1978), pp. 231-252

38 J.S. Isaacson, J.M. Solis, R.A. Nicoll. Local and diffuse synaptic actions of GABA in the hippocampus. Neuron, 10 (1993), pp. 165-175

39 E. Kato, K. Kuba. Inhibition of transmitter release in bullfrog sympathetic ganglia induced by $\boldsymbol{v}$-aminobutyric acid. J. Physiol., Lond., 298 (1980), pp. 271-283

$40 \mathrm{~K}$. Kato, M. Goto, H. Fukuda. Baclofen: inhibition of the release of L-[ $\left.{ }^{3} \mathrm{H}\right]$ glutamate and L- $\left[{ }^{3} \mathrm{H}\right]$ aspartate from rat whole brain synaptosomes. Gen. Pharmac., 13 (1982), pp. 445-447

41 D.I.B. Kerr, J. Ong, G.A.R. Johnston, J. Abbenante, R.H. Prager. 2-Hydroxy-saclofen: an improved antagonist at central and peripheral GABA ${ }_{B}$ receptors. Neurosci. Lett., 92 (1988), pp. 92-96

42 P.G. Kostyuk, N.S. Veselovsky, S.A. Fedulova. Ionic currents in the somatic membrane of rat dorsal root ganglion neurons - II. Calcium currents. Neuroscience, 6 (1981), pp. 2431-2437

43 A. Lev-Tov, D.E.R. Meyers, R.E. Burke. Activation of type B $\boldsymbol{y}$-aminobutyric acid receptors in the intact mammalian spinal cord mimics the effects of reduced presynaptic $\mathrm{Ca}^{2+}$ influx. Proc. natn. Acad. Sci. U.S.A., 85 (1988), pp. 5330-5334

44 G. Levi, M. Raiteri. Carrier-mediated release of neurotransmitters. Trends Neurosci., 16 (1993), pp. 415-419

45 R.A. Levy. The role of GABA in primary afferent depolarization. Prog. Neurobiol., 9 (1977), pp. 211-267

46 R. Llinás, I.Z. Steinberg, K. Walton. Relationship between presynaptic calcium current and synaptic potential in squid giant synapse. Biophys. J., 33 (1981), pp. 323-351

47 T. Matsushima, J. Tegner, R.H. Hill, S. Grillner. GABA ${ }_{B}$ receptor activation causes a depression of low- and high-voltage-activated $\mathrm{Ca}^{2+}$ currents, postinhibitory rebound, and postspike afterhyperpolarization in lamprey neurons. J. Neurophysiol., 70 (1993), pp. 2606-2619

48 D.R. Matteson, C.M. Armstrong. Properties of two types of calcium channels in clonal pituitary cells. J. gen. Physiol., 87 (1986), pp. 161-182

49 D.J. Maxwell, W.M. Christie, A.D. Short, A.G. Brown. Direct observations of synapses between GABAimmunoreactive boutons and muscle afferent terminals in lamina $\mathrm{VI}$ of the cat's spinal cord. Brain Res., 530 (1990), pp. 215-222

50 D. Miceli, J. Repérant, J.-P. Rio, M. Medina. GABA immunoreactivity in the nucleus isthmo-opticus of the centrifugal visual system in the pigeon: a light and electron microscopic study. Vis. Neurosci., 12 (1995), pp. 425-441 
51 I. Mody, Y. De Koninck, T.S. Otis, I. Soltesz. Bridging the cleft at GABA synapses in the brain. Trends Neurosci., 17 (1994), pp. 517-525

52 T. Nakao, A. Ishizawa. Development of the spinal nerves in the lamprey: I. Rohon-Beard cells and interneurons. J. comp. Neurol., 256 (1987), pp. 342-355

53 O.P. Ottersen. Postembedding light- and electron microscopic immunocytochemistry of amino acids: description of a new model system allowing identical conditions for specificity testing and tissue processing. Expl Brain Res., 69 (1987), pp. 167-174

54 O.P. Ottersen. Quantitative electron microscopic immunocytochemistry of neuroactive amino acids. Anat. Embryol., 180 (1989), pp. 1-15

55 E. Persohn, P. Malherbe, J.G. Richards. In situ hybridization histochemistry reveals a diversity of $\mathrm{GABA}_{A}$ receptor subunit mRNAs in neurons of the rat spinal cord and dorsal root ganglia. Neuroscience, 42 (1991), pp. 497-507

56 J.-P. Pin, J. Bockaert. Two distinct mechanisms, differentially affected by excitatory amino acids, trigger GABA release from fetal mouse striatal neurons in primary culture. J. Neurosci., 9 (1989), pp. 648-656

57 C.M. Rovainen. Physiological and anatomical studies on large neurons of the central nervous system of the sea lamprey (Petromyzon marinus). II. Dorsal cells and giant interneurons. J. Neurophysiol., 30 (1967), pp. 1024-1042

58 P. Rudomín, I. Jimenez, M. Solodkin, S. Duenas. Sites of action of segmental and descending control of transmission on pathways mediating PAD of la- and Ib-afferent fibers in cat spinal cord. J. Neurophysiol., 50 (1983), pp. 743-769

59 M. Schwarz, T. Klockgether, U. Wullner, L. Turski, K.-H. Sontag. $\delta$-Aminovaleric acid antagonizes the pharmacological actions of baclofen in the central nervous system. Expl Brain Res., 70 (1988), pp. 618626

60 Somogyi P. (1989) Synaptic organization of GABAergic neurons and $G A B A_{A}$ receptors in the lateral geniculate nucleus and visual cortex. In Neuronal Mechanisms of Visual Perception (eds Lam D. K.-T. and Gilbert C. D.), pp. 35-62. Portfolio, Texas.

$61 \mathrm{H}$. Steffens, E.D. Schomburg, H.B. Behrends. Segmental reflex pathways from cutaneous afferents to $\alpha$ motoneurones in the tortoise. Neurosci. Lett., 1 (Suppl.) (1978), p. S104

62 J.M. Stirling, A.J. Cross, T.N. Robinson, A.R. Green. The effects of $G_{A B A_{B}}$ receptor agonists and antagonists on potassium-stimulated $\left[\mathrm{Ca}^{2+}\right]_{\text {in }}$ in rat brain synaptosomes. Neuropharmacology, 28 (1989), pp. 699704

63 G.J. Stuart, S.J. Redman. The role of $\mathrm{GABA}_{A}$ and $\mathrm{GABA}_{B}$ receptors in presynaptic inhibition of la EPSPs in cat spinal motoneurones. J. Physiol., Lond., 447 (1992), pp. 675-692. (in Russian)

64 Z.A. Tamarova, A.I. Shapovalov, B.I. Shiriaev. Synaptic effects in the endings of individual primary afferent fibers mono- and polysynaptically connected to spinal motor neurons. Fiziol. Zh. SSSR, 67 (1981), pp. 1511-1520. (in Russian)

65 S.W. Thompson, P.D. Wall. The effect of GABA and 5-HT receptor antagonists on rat dorsal root potentials. Neurosci. Lett., 217 (1996), pp. 153-156

66 Vesselkin N. P., Batueva I. V., Buchanan J. T., Kurchavyi G. G., Tsvetkov E. A., Sagatelyan A. K., Suderevskaya E. I., Repérant J., Rio J.-P. and Adanina V. O. (1997) Different functional properties of neurons in spinal cord of lower vertebrates. In Abstr. of 33 Internat. Congr. of Physiol. Sci. IUPS. Abstr. L072.05. St Petersburg.

67 Vesselkin N. P., Repérant J., Batueva I. V., Buchanan J. T., Adanina V. O., Rio J.-P. and Tsvetkov E. A. (1997) GABA-immunopositive boutons contact the primary afferent terminals in the lamprey spinal cord. In Abstr. of 17th Eur. Winter Conf. of Brain Res. Arc 2000 (France), pp. 73. 